\title{
Uber és taxi egymás mellett - új piaci modellek hagyományos árdiszkriminációval
}

\begin{abstract}
A tanulmány ismerteti az Uber által életre hívott és azóta több más vállalkozás által is alkalmazott üzleti modellt. Megmutatja, hogy a számítástechnika és a mobiltechnológia fejlődése, valamint a személyautó-tulajdonosok számának növekedése szinte magától értetődően teremtette meg egy új piaci modell kiépülésének elveit. Foglalkozik azzal, hogy az egyes piaci szereplők hogyan viszonyulnak az új üzleti modellhez. Külön hangsúlyt fektet a jutaléksávok rendszerére, amelyben a megtett utaskilométerek függvényében a másodfokú árdiszkrimináció szabályainak megfelelően csökkennek a cégek által a gépkocsivezetőktől beszedett jutalékok. A szerző felhívja a figyelmet a modell ellentmondásosságára, a belöle származó előnyökre és hátrányokra is. Megmutatja, hogy az Európai Bíróság 2017 végi döntése a hátrányok elkerülése érdekében született. Végezetül felhívja a figyelmet a modell bizonytalanságaira és a jövőbeli esetleges változásokra.

Journal of Economic Literature (JEL) kód: L11, L14, L23, L53, O33, R49.
\end{abstract}

\section{Bevezetés}

Az Uber az utóbbi időben gyakran került a hírportálok vezető helyére. A San Franciscó-i székhelyű vállalat alapítása, 2009 óta piaci bevételét és az utazások számát tekintve rendületlenül növekszik. ${ }^{1}$ Az Egyesült Államok egészében elterjedt és külföldön is terjeszkedő vállalatot azonban 2017 első harmadában négy, különböző pozíciókban tevékenykedő felső vezetője is elhagyta (Kollewe [2017a]), köztük az Uber vezérigazgatója, Travis Kalanick, aki Garrett Camppal együtt alapította a vállalatot. ${ }^{2}$ A 2017 nyarán

* Berde Éva a Budapesti Corvinus Egyetem egyetemi tanára (e-mail: eva.berde@uni-corvinus.hu).

${ }^{1}$ A növekedés a piaci térhódításra és a bevételre vonatkozik, mert a vállalat 2016 negyedik és 2017 első negyedében már komoly veszteségeket szenvedett el (Calfas [2017]), 2017-ben pedig összességében mintegy 7,5 milliárd dollár volt a vesztesége (Livemint [2018]).

${ }^{2}$ Kalanickot távozása előtt többen és többféle tevékenységéért is megvádolták, beleértve a szexuális zaklatást is. Azon a világhálót is bejáró videófelvételén, amely megörökíti az egyik Uber-sofőrrel való agresszív vitáját, látható, hogy Kalanick a sofört győzködi az Ubernek járó jutalék emelésének jogosságáról (a https://www.theguardian.com/technology/2017/feb/28/uber-ceo-travis-kalanick-driverargument-video-fare-prices).

A kézirat első változata 2017. augusztus 27-én érkezett szerkesztőségünkbe.

DOI: http://dx.doi.org/10.18414/KSZ.2018.6.650 
kinevezett vezérigazgató, Dara Khosrowshahi igyekszik kevésbé agresszív stratégiát megvalósítani, és próbál megfelelni az egyes országok szabályozási feltételeinek, de az Uber „kulturális szokásainak” megváltoztatása meglehetősen nehéz.

Ami az Uber európai térhódítását illeti, a 2010-es évek elejétől több európai országban is megpróbált piacra lépni, többnyire az adott ország taxivállalatainak erös tiltakozása és a szabályozó hatóságok nemtetszése ellenére. Volt olyan ország, ahonnan a vállalat kénytelen volt kivonulni, másutt pedig csak nagyon visszafogott keretek közt müködhetett, és alig-alig volt olyan ország, illetve területi egység, ahol sikerült az eredeti piaci modell szerint tevékenykednie. Az Európai Bíróság 2017. decemberi 20-i döntése értelmében az Európai Unió országaiban müködő Uber-vállalatok ugyanúgy személyszállító szolgáltatást nyújtanak, mint a taxitársaságok, és ezért azonos szabályozási feltételek vonatkoznak rájuk (ECJ [2017]). Nem tekinthetők tehát kizárólag számítástechnikai közvetítést nyújtó szolgáltatóknak, amelyek mentesülnének a taxiszolgáltatókra érvényes követelmények alól. Mint személyszállító társaságok az adott ország személyszállítását szabályozó törvények hatálya alá tartoznak, ezért az egyes országokban különbözhetnek a müködési feltételeik. Ezek a feltételek azonban semmiképpen sem azonosak a számítástechnikai közvetítô cégek feltételrendszerével.

A tanulmány fö kérdése az, hogy mi is ez a sok indulatot kiváltó, egyesek részéröl különösen nagy ellenérzéssel fogadott, mások részéről lelkesen támogatott szolgáltatás. Mind az Uber-sofőrök mint munkát végző és jövedelmet élvező munkaerö-piaci szereplők, mind az Uber cég mint a foglalkoztató vállalat, ${ }^{3}$ mind pedig a fogyasztók szemszögéböl keressük a választ. Megmutatjuk, hogy az Uber-cégek, kihasználva szabályozásonkívüliségüket, jelentős profitra tehetnek szert. Emellett felhívjuk a figyelmet az Uber által alkalmazott foglalkoztatási forma veszélyeire is.

A továbbiakban megismerkedünk az Uber eredeti, egyesült államokbeli piaci modelljével, majd azzal, hogy miként müködik az Európai Unió országaiban. Megmutatjuk, hogy az Uber eredeti - elektronikus utasközvetító platformra épülő - jutalékos piaci modellje miképpen segíti elő a profit növekedését, és hogyan befolyásolja a gépkocsivezetők bevételét. Külön kitérünk a munkaerőpiaci hatásokra is. Végül ezen új piaci modell várható fejlődését, az ehhez kapcsolódó szabályozási dilemmát vázoljuk.

\section{Az Uber az Egyesült Államokban és Európában}

Az Uber, majd alapítása után hamarosan megjelenő amerikai versenytársai, valamint a más földrészeken hozzá hasonlóan müködő vállalatok megváltoztatták a rendeléses utasszállítás piacát. A taxizás „forradalma”4 egy olyan időszakban következett be, amikor a forgalomban levő személygépkocsik óriási száma, a számítástechnikai szoftverek jelentős fejlődése, valamint a mobiltelefonok általánossá válása szinte kínálta az újfajta szolgáltatási módot. Már csak az Uber ötlete hiányzott, és azonnal el is indult ez a

\footnotetext{
${ }^{3}$ Bár az Uber magát nem tartja hagyományos értelemben vett foglalkoztatónak.

${ }^{4}$ A „forradalom” kifejezést Hahn-Metcalfe [2017]-ból kölcsönöztem.
} 
modern taxizási forma, ${ }^{5}$ amelyet sok szerző a megosztáson alapuló (sharing economy), új típusú iparágak egyik fö reprezentánsának tart (lásd például Szabó [2017]). ${ }^{6} \mathrm{Az}$ Uber jó helyen és jó időben dolgozta ki jó ötletét, ügyesen kihasználta a szabályozási hézagot, és ezzel egy újfajta piaci modellt teremtett. Összehozza az utasok igényét a saját személyautójukon szállítást vállaló gépkocsivezetők kínálatával, és miközben partnernek nevezi a vele szerződést kötő autóvezetőket, komoly jutalékot kér az általa kifejlesztett szoftver használatáért. Az Uber növekvő népszerüségét mutatja az 1. táblázat, amelyben jól látható az Uberrel New Yorkban megtett utak számának növekedése.

\section{1. táblázat}

A napi átlagos Uber-utazások számának alakulása

New Yorkban, 2015-2017

\begin{tabular}{lc}
\hline Időpont & $\begin{array}{c}\text { Az Uberrel megtett utak } \\
\text { átlagos száma }\end{array}$ \\
\hline 2015. július & 91920 \\
2016. január & 136500 \\
2016. július & 173920 \\
2017. január & 231500 \\
2017. július & 304800 \\
2018. január & 383530 \\
\hline
\end{tabular}

Forrás: Schneider [2016].

Bár szolgáltatását tekintve az a piaci modell, amelyet az Uber az Egyesült Államokban kialakított, hasonlít a taxiéhoz, az utazáskor létrejövő kapcsolat mindhárom része lényeges különbségeket is tartalmaz. A taxitól eltérően az utasok a kocsit csak szoftveres alkalmazás segítségével tudják megrendelni. A szoftver alapvetően a mobiltelefonokon, de más internetre kapcsolódó eszközön is müködik, és fizetni is csak a szoftver közreműködésével lehet (kivéve néhány fejlődő országot, ahol - mint ahogy Wyman [2017] írja - lehetséges a készpénzes fizetés is). Az árak a kereslettől függnek, és általában jóval a hagyományos taxi árai alatt mozognak, vagyis az utasok számára az „uberezés” olcsóbb, mint a hagyományos taxi. A szoftver által meghatározott úgynevezett hullámzó árak (surge price) azonban túlkereslet esetén akár lényegesen is felülmúlhatják a hagyományos taxik árait. A kereslethez igazodó árak eredményeként a piaci egyensúly hamar kialakul, és a nagyobb fizetési hajlandóságú fogyasztók a legforgalmasabb időszakokban is kocsihoz jutnak. A fogyasztók részére alapvető különbség még a hagyományos taxikhoz képest, hogy az Egyesült Államokban

\footnotetext{
${ }^{5}$ Az Uber történetét Wyman [2017], Huet [2015], valamint Hahn-Metcalfe [2017] mutatja be. A cikk bevezető részében a tények leírásakor erre a három cikkre támaszkodtam.

${ }^{6}$ Szabó [2017] megosztásos iparágként definiálja az Ubert, utalva arra, hogy sok szerző ezt a szolgáltatást inkább a hozzáférést biztosító iparág (access economy) részének tekinti. Jelen cikk az Uber és a soförök profitérdekeltségét mutatja be. Ennek alapján a kocsik megosztása inkább a hozzáférést biztosító iparág részét képezi, mintsem az anyagi érdek nélküli, közös eszközhasználatot.
} 
működő Uber egyelöre nem vállalja az utasok biztosítását, ezért baleset esetén kizárólag a gépkocsivezető vonható felelősségre. ${ }^{7}$

Az egyesült államokbeli Ubert mint vállalkozást az különbözteti meg a taxivállalatoktól, hogy gépkocsivezetői magánszemélyek - tehát se nem alkalmazottak, se nem vállalkozók -, akik magánszerződést kötnek a társasággal. Hall-Krueger [2016] az autóvezető partner (driver-partner), Harris-Krueger [2015] és sokan mások pedig a független szerződő fél elnevezést használják (independent contractor), és szinte valamennyi szerző - mint például Bolton [2015] - alternatív megnevezésként a szabadúszó (freelancer) kifejezést is alkalmazza. A magánszemély gépkocsivezetők esetében azonban egyelöre semmi olyan biztonsági vagy szervezeti forma nem kapcsolódik az alkalmazáshoz, amely a betegség vagy öregség miatt munkaképtelen autóvezetőket finanszírozná, vagy fizetett szabadságot biztosítana a részükre. ${ }^{8}$

Az egyesült államokbeli Uber-társaságok önmagukat nem tekintik személyszállító cégnek, hanem utasközvetítő számítástechnikai platformnak. San Franciscóban, illetve más egyesült államokbeli városokban - sőt bizonyos szövetségi államokban is - perrel próbálták meg elüzni az Ubert. Ma már azonban az Egyesült Államok majdnem minden államában szabadon és utasközvetítő platformként működhet. Az Uber Európában is hasonló módon szeretett volna tevékenykedni, ez azonban csak néhol és csak ideiglenesen sikerült.

Végül a harmadik fél, az autóvezetők számára az Uber-fuvarozás abban is eltér a hagyományos taxizástól, hogy úgy használhatják az anyacég közvetítő szolgáltatását, hogy nem kell alkalmazotti vagy vállalkozói formában dolgozniuk. Emellett nem kell teljesíteniük a taxikkal kapcsolatos, országonként és esetleg városonként is különböző, de valamely formában mindenütt létező, belépést korlátozó szabályokat. Az Egyesült Államokban az uberezéshez például nincs szükségük a nem is olyan régen vagyonokat érö vezetői oklevél (medallion) megszerzésére. ${ }^{9}$ Továbbá a gépkocsivezetők nincsenek arra kötelezve, hogy külön vezetői vizsgát tegyenek, elegendő, ha személygépkocsira érvényes jogosítványuk van, és nem kell külön taxisengedélyt szerezniük. Alapesetben autóikat sem kell megkülönböztetniük a tagállam vagy a társaság által megszabott módon, és - bár ez a legtöbb taxitársaságra is igaz - senki nem szabja meg, hogy hány órát vezessenek, maguk határozzák meg a munkaidejüket.

Az Uber az Egyesült Államokban meghonosított piaci modellt sok más országban is igyekezett bevezetni. Észak-Amerikában, Ausztráliában és Délkelet-Ázsiában

${ }^{7}$ Barglind [2015] ehhez kapcsolódóan írja le egy hatéves kislány esetét, akit 2013. újév éjszakáján ütött el San Franciscóban egy Uber-soför. A család tagjainak a per során nem sikerült érvényre juttatniuk kártérítési igényüket. A biztosítás területén azonban már tettek lépéseket az Uber által szervezett általános érvényü utas- és balesetbiztosítás érdekében.

${ }^{8}$ Hahn-Metcalfe [2017] leírja azt a példaszerü esetet, amelyben egy londoni esküdtszék két Ubersoförnek adott igazat, és elöírta, hogy az Uber köteles részükre fizetett szabadságot és minimumbért biztosítani. A példa hosszú ideig csak kivételnek számított, de az Európai Bíróság 2017. decemberi döntése (ECJ [2017]) alapján ma már minden olyan uniós országban jár a szabadság az Uber-soföröknek, ahol a hagyományos taxisoförök számára is érvényben van ez a juttatás.

${ }^{9}$ New Yorkban 2013 júniusában átlagosan még 1,05 millió dollárért keltek el a hagyományos taxiengedélyek, de 2014 végére már 20 százalékot vesztettek az értékükből, és ez csak az értékcsökkenés kezdete volt (Barglind [2015]). 
komolyabb sikereket ért el, Európában azonban a kezdetektől fogva nemcsak a taxiscégek és azok alkalmazottai, hanem a kormányok is meglehetős ellenérzéssel fogadták. Magyarországon például 2016 nyarán felfüggesztették tevékenységüket, és a vállalat gyakorlatilag elhagyta az országot. Szinte minden európai ország kormányzata egyetértett abban, hogy az Uber számára is a taxitársaságokkal azonos szabályozási feltételeket kell szabni, de nem mindenütt sikerült ezeket a feltételeket egyértelmüen elfogadtatniuk.

Az Uber 2015-ben megnyerte ugyan a londoni közlekedési társaság (Transport for London, TfL) ellene indított perét, és ezáltal mind a müködése, mind mobilapplikációja törvényessé vált Londonban, de a legtöbb európai országban eredeti formájában teljesen ellehetetlenítették a cég működését (Kollewe [2017b]). A TfL 2017 őszén ismét betiltotta a londoni Uber müködését, ami ellen az Uber megint fellebbezett (Ram és szerzötársai [2017]). A fellebbezés eredményére várva egyelöre továbbra is az egyesült államokbeli piaci modellnek megfelelően, szabadon müködik, kihasználva, hogy a döntés még nem emelkedett törvényerőre.

Az Európai Unió országaiban fuvarozó Uber-társaságok jövőjét alapvetően meghatározza az Európai Bíróság 2017. december 20-i határozata (ECJ [2017]). A döntés a barcelonai hivatásos taxisok szövetsége által 2014-ben az Uber ellen benyújtott, tisztességtelen versenyre hivatkozó panasza alapján született. Az Európai Bíróság döntése értelmében az Uber ugyanolyan hívásos személyszállító cég, mint a korábban bejegyzett taxitársaságok, és nem elektronikus utasközvetítő platform. Ezért az EU államaiban az adott országbeli, a taxitársaságokra érvényes szabályozás vonatkozik az Uber-cégekre is. A 2. táblázatban összefoglaljuk, hogy az Európai Unió országaiban milyen formában müködött az Uber vállalat 2017. december 20 -án, az Európai Bíróság döntésekor.

\section{2. táblázat}

Az Uber megengedett működési módja az Európai Unió országaiban 2017. december 20 -án

\begin{tabular}{|c|c|c|}
\hline Ország & Az Uber müködési módja & Megjegyzés \\
\hline Ausztria & Csak engedéllyel & \\
\hline Belgium & Csak engedéllyel & \\
\hline Bulgária & Nem engedélyezett & $\begin{array}{l}\text { 2015-ben a Legfelsőbb Bíróság döntését } \\
\text { követően elhagyta az országot }\end{array}$ \\
\hline Ciprus & Nem engedélyezett & Soha nem lépett be az országba \\
\hline $\begin{array}{l}\text { Cseh } \\
\text { Köztársaság }\end{array}$ & $\begin{array}{l}\text { Magánszemély } \\
\text { magánszemélynek }\end{array}$ & $\begin{array}{l}\text { Változni fog a működési feltétele, meg kell majd } \\
\text { felelnie a helyi szabályoknak }\end{array}$ \\
\hline Dánia & Nem engedélyezett & $\begin{array}{l}\text { Áprilisban hagyta el az országot, miután } \\
\text { változtak a taxiszolgáltatás szabályai }\end{array}$ \\
\hline $\begin{array}{l}\text { Egyesült } \\
\text { Királyság }\end{array}$ & Csak engedéllyel & $\begin{array}{l}\text { A gyakorlat azonban ellentmondásos; } \\
\text { Londonban például a korábban magánszemély } \\
\text { által magánszemélynek nyújtott szolgáltatás } \\
\text { jelenleg is működik, miközben a bírósági } \\
\text { fellebbezés eredményére várnak }\end{array}$ \\
\hline
\end{tabular}

Észtország Csak engedéllyel 


\section{A 2. táblázat folytatása}

\begin{tabular}{|c|c|c|}
\hline Ország & Az Uber müködési módja & Megjegyzés \\
\hline Finnország & $\begin{array}{l}\text { Müködési lehetőségéről } \\
\text { még nincs döntés }\end{array}$ & $\begin{array}{l}\text { Júliustól kedve várhatóan ismét nyújthat } \\
\text { majd magánszemély magánszemélynek } \\
\text { szolgáltatást, mert a taxizásra vonatkozó } \\
\text { törvények változni fognak }\end{array}$ \\
\hline Franciaország & Csak engedéllyel & \\
\hline Görögország & Csak engedéllyel & \\
\hline Hollandia & Csak engedéllyel & \\
\hline Horvátország & Csak engedéllyel & \\
\hline Írország & Csak engedéllyel & \\
\hline Lengyelország & $\begin{array}{l}\text { Magánszemély } \\
\text { magánszemélynek }\end{array}$ & $\begin{array}{l}\text { Változni fog a müködési feltétele, meg kell majd } \\
\text { felelnie a helyi szabályoknak }\end{array}$ \\
\hline Lettország & Nem engedélyezett & Soha nem lépett be az országba \\
\hline Litvánia & Csak engedéllyel & \\
\hline Luxemburg & Nem engedélyezett & Soha nem lépett be az országba \\
\hline Magyarország & Nem engedélyezett & $\begin{array}{l}\text { 2016-ban elhagyta az országot, mert a szabályozás } \\
\text { nem biztosított számára internetelérhetőséget }\end{array}$ \\
\hline Németország & Csak engedéllyel & \\
\hline Olaszország & Csak engedéllyel & \\
\hline Portugália & Csak engedéllyel & \\
\hline Románia & $\begin{array}{l}\text { Magánszemély } \\
\text { magánszemélynek }\end{array}$ & $\begin{array}{l}\text { Feltételezhetően változni fog a működési feltétele, } \\
\text { meg kell majd felelnie a helyi szabályoknak }\end{array}$ \\
\hline Spanyolország & Csak engedéllyel & \\
\hline Svédország & Csak engedéllyel & \\
\hline Szlovákia & $\begin{array}{l}\text { Magánszemély } \\
\text { magánszemélynek }\end{array}$ & $\begin{array}{l}\text { Változni fog a müködési feltétele, meg kell majd } \\
\text { felelnie a helyi szabályoknak }\end{array}$ \\
\hline Szlovénia & Nem engedélyezett & Soha nem lépett be az országba \\
\hline
\end{tabular}

Forrás: Posaner-Sauer [2017].

A 2. táblázatban a magánszemély által magánszemélynek nyújtott szolgáltatás azt jelenti, hogy taxiengedéllyel nem rendelkező soför is szállíthatja az utasokat. A gépkocsivezetőt és az utast pedig az Uber szoftverje kapcsolja össze. Ha egy országban a hagyományos taxitársaságnak is lehet taxiengedély nélküli autóvezetője, akkor ez az Uber számára a jövőben sem tiltott, és a jelzett kapcsolati forma a továbbiakban is fennmaradhat, illetve létrejöhet. Az engedélyhez kötött szolgáltatás azonban megköveteli, hogy a gépkocsivezetök ugyanúgy rendelkezzenek taxiengedéllyel, mint a többi hívásos utasszállító szolgáltatás gépkocsivezetői. Továbbá minden más szempontból is mind az Uber cégre, mind gépkocsivezetőire érvényesek a taxicégekre vonatkozó szabályok. A 2. táblázatban bemutatott helyzethez képest azonban sokszor előfordul ellentmondásos szituáció, helyi kivételek, illetve az Uber továbbra is meglehetősen 
offenzív stratégiája akkor is vezethet olyan szolgáltatási módokhoz, amelyek tulajdonképpen tilosak az adott országban.

A 2. táblázatból kitünik, hogy a legtöbb európai uniós országban a taxicégek decemberben is csak engedéllyel rendelkező gépkocsivezetőt alkalmazhattak, ily módon az Uber egyesült államokbeli piaci modellje sem valósulhatott meg. Néhány országban ugyan még magánszemély is nyújthatott magánszemélynek Uberszolgáltatást, de ez a jövőben várhatóan meg fog változni, és az Uber kénytelen lesz megfelelni a helyi szabályoknak.

\section{Az elektronikus utasközvetítő platformmal működő vállalkozások - Ublyft}

A továbbiakban a „klasszikus” magánszemélytől magánszemélyig közvetítő és jutalékot levonó szolgáltató verus „hagyományos” taxivállakozás profitlehetőségeit vizsgáljuk. Előtérbe helyezzük a gépkocsivezetőkkel szemben alkalmazható árdiszkriminációt, majd pedig a gépkocsivezetők munkaerőpiaci helyzetével kapcsolatosan vázolunk néhány összefüggést.

Az Uber által kifejlesztett, elektronikus utasközvetítő platformra épülő üzleti modelljét azóta több vállalkozás is átvette: 2012 óta a Lyft elnevezésủ cég az Ubernek közvetlen versenytársa lett az Egyesült Államokban, illetve 2015-ig még a hasonló elveken működő Sidecar is piaci résztvevő volt, ${ }^{10}$ továbbá más országokban és más földrészeken más társaságok által is megvalósult már a hivatásos utasszállítás Uber által kifejlesztett üzleti modellje. Ebben a cikkben a két társaság nevének összevonásából adódó Ublyft elnevezést alkalmazzuk minden olyan esetben, amikor az elemzés általános jellegü, bármely elektronikus utasközvetítő platformra vonatkoztatható. Amikor pedig az Uber vagy a Lyft kifejezést használjuk, akkor egyértelmüen a megnevezett társaságra kell gondolnunk.

Az Uber, majd a Lyft felbukkanásakor összességében mind a potenciális új gépkocsivezetők, mind a fogyasztók pozitívan fogadták a lehetőségeket. A hagyományos taxitársaságok autóvezetői és maguk a társaságok tulajdonosai azonban tiltakoztak piacra lépésük ellen. Nem egyszerüen csak olyan vetélytársat láttak bennük, amelyek tevékenységükkel veszélyeztetik az általuk már megszerzett piaci részesedést, hanem úgy érezték, hogy a másfajta üzleti modell és az általa igényelt kivételezett szabályozási háttér jogtalanul kedvez az elektronikus utasközvetítő platformmal működő vállalkozásoknak.

A hagyományos taxizásban érdekeltek jól látták a helyzetet. Az Ublyft egyre több utazást bonyolít le, és jelentős részben a taxik piaci lehetőségeinek rovására. ${ }^{11} \mathrm{~A}$ kezdetek-

${ }^{10}$ A fenti információk forrásául szolgáló Schuetz [2016] a hasonló jellegű közlekedési vállalatok közt még felsorolja a Getaround és a RelayRides céget is, ezek azonban profiljukat tekintve az autókölcsönző, nem pedig a taxicégek versenytársai.

${ }^{11}$ New Yorkban például Schneider [2016] grafikonpontjainak értékei alapján kiszámítható, hogy az Uberrel és a Lyfttel együttesen 350760 utazást bonyolítottak le 2017. április 29-én, a hagyományos sárga taxikkal a hozzá időben legközelebbi, statisztikát rögzítő napon, április 30-án 334865 utat. Az 
kor azonban a hagyományos taxivállalatok gépkocsivezetőinek legfeljebb a jövőjüket, és nem a jelenüket illetően volt okuk aggodalomra. Mint ahogy Pásztor [2017] is leírja, mindaddig, amíg az Ublyft konstans, 20 százalék körüli jutalékot kért a szolgáltatásért, addig a gépkocsivezetők döntési helyzete attól függött, hogy mennyi időt szántak a vezetésre. Azoknak, akik részidőben kívántak gépkocsivezetőként dolgozni, érdemesebb volt az Ublyftet választaniuk, a teljes munkaidőben gépkocsivezetőként dolgozók pedig jobban tették, ha megmaradtak a hagyományos taxivállalatoknál.

Az Ubernél dolgozók döntő része ma is csak részmunkaidőben választja ezt a jövedelemszerzési tevékenységet. Hall-Krueger [2016] a Benenson Strategy Group által 2014-ben készített felmérést használva azt írja, hogy az Egyesült Államokban a taxisoförök mindössze 4 százaléka dolgozik heti 15 óránál kevesebbet, míg ugyanez az arány az Ubernél 51 százalék. Ezeket az adatokat alátámasztja, hogy 2014-ben az Uber-soförök körülbelül kétharmadának volt másik - fél- vagy teljes idejü - állása. Az elektronikus utasközvetítő platformra épülő üzleti modell erősen támogatja a részmunkaidős foglalkoztatást.

Ezért is olyan népszerű a potenciális gépkocsivezető partnerek körében. Amikor szükségük van pluszjövedelemre, és idejük engedi, „kiugranak” egy kis vezetésre, és azonnal meg tudják növelni a család rendelkezésére álló költségvetést. Ehhez nem kell drága engedélyeket vásárolni, és nem kell egy taxitársaság telefonos operátorának a kegyeit lesni, hogy minél több utasuk legyen. Minden egyértelmüen és azonnal történik. Az utas a mobiljára letöltött szoftver segítségével rendeli meg a kocsit, és ha nagy a kereslet a kocsik iránt, akkor a gépkocsivezető ugyanazért az útért több bevételre tesz szert. Ő is a mobilján keresztül tájékozódik, ide érkezik az utas rendelése, amit, ha akar, visszaigazol, és ily módon elfogad. Az Egyesült Államokban és a gazdaságilag fejlett országokban pénzt közvetlenül nem cserélnek, a javadalmazást a gépkocsivezető a szoftveren keresztül kapja meg, úgy, hogy előzőleg szintén a szoftver levonja a szolgáltató cég részesedését.

Az Ublyft versus taxi esetében a Christensen-Bower [1996] cikket idézö romboló újítás (disruptive innovation) fogalmát használja számos szerző (például CramerKrueger [2016]). A taxiiparágba kívülröl érkezett új piaci modell valóban több szempontból romboló erejű a régebbi piaci szereplők, a hagyományos taxivállalatok számára. Ezért ök mindent elkövetnek annak érdekében, hogy megakadályozzák az új résztvevők piaci belépését, illetve ha már bejutottak a hívásos személyszállítás területére, akkor a hagyományos szereplök igyekeznek ellehetetleníteni öket. Amennyiben elfogadjuk Stigler [1971] érvelését, akkor a hagyományos taxivállalatok egyik legfontosabb fegyvere országuk szabályozó hatóságának mozgósítása, amivel számos esetben lassítják a fejlődést, és csökkentik a jólétet. Cohen és szerzőtársai [2016] számításai alapján, ha az Egyesült Államokban hirtelen megszünne az Uber, az rövid távon évenként dollármilliárdokban mérhető fogyasztói többlet elvesztését jelentené.

adatok természetesen csak tájékoztató jellegüek, a sárga taxik statisztikáit vasárnaponként, az Uberét és a Lyftét szombatonként rögzítették. Emellett a domináns sárga taxik mellett New Yorkban is lehet más „hagyományos” taxit bérelni. Tendenciáját tekintve azonban a szerző grafikonján egyértelmüen látszik, hogy a hagyományos taxikat reprezentáló sárga taxik igénybevétele rohamosan csökken, az Uber és a Lyft használata pedig gyorsan növekszik. 
A jóléti helyzet megítélése azonban még a fogyasztói többlet esetében sem ilyen egyértelmü. Lehetséges ugyan, hogy az elektronikus utasközvetítő platformmal müködő vállalkozások megnövelik a keresleti görbe alatti, árig tartó területet (a nettó fogyasztói többletet), de más megközelítésből létezik a nettó fogyasztói többletet csökkentő hatása is, melyet Cohen és szerzötársai [2016] egyáltalán nem vettek figyelembe. Egyelöre még számos, biztonságot garantáló szabályozási elem hiányzik, ami mindenképpen csökkenti a fogyasztói jólétet. E gondokat maguk a szolgáltatást nyújtó társaságok is érzékelik, a Rideshareapps [2017] például biztonsági elöírások hiányával kapcsolatos problémákról ír. Ezekkel kapcsolatosan sok szerző (például Posen [2015]) arra a következtetésre jut, hogy az Ublyft esetében egy újfajta szabályozásra van szükség.

Az Ublyft sok területen igyekszik lemásolni a taxiknál megszokott müködési formákat, a taxiiparág pedig nemcsak ellenállást mutat az Ublyft hatására, hanem maga is próbálkozik bizonyos újítások bevezetésével. DeMasi [2016] bemutatja, hogyan differenciálta kocsijait az Uber, amelyek között van olyan is, amely a luxustaxikkal egyenértékủ szolgáltatást nyújt (ez az Egyesült Államokban az Uber Black), illetve olyan is, amely a sima taxiknak megfelelő, de azoknál általában sokkal alacsonyabb viteldíjat szabó alapkocsi (az Egyesült Államokban ez az UberX). A továbblépés folyamatos szándékát jelzi, hogy ma már müködnek olyan Uber-kocsik, amelyek több utas egy időben történő szállítására specializálódtak, ezzel egyben a kisbuszos személyszállításnak is kihívást jelentenek. A differenciálást illetően többfajta minőség kínálatával a Lyft is próbálta követni közvetlen versenytársát.

Ezzel párhuzamosan a hagyományos taxitársaságok többsége az új Ublyftmodellből igyekezett bevezetni a szoftveres autórendelés lehetőségét, ezek a szoftverek azonban az árképzésben nem kaptak szerepet. A hagyományos taxik esetében továbbra is müködik a diszpécseren keresztüli telefonos rendelés, valamint az utcai leintés, illetve a taxisstandokon történő autófoglalás, így ebből a szempontból a hagyományos taxitársaságok tulajdonképpen előnyt élveznek. Ez az előny azonban a számítástechnika jelenlegi fejlettségi szintjén és a mobiltelefonok elterjedtsége mellett nem tekinthető igazán piacbefolyásoló tényezőnek, mert az Ublyft-kocsik rendelése igen egyszerü és gyors.

A hagyományos taxitársaságok igyekeznek az új modell többsávos jutalékrendszerét is átvenni, és gyakran nemcsak átalánydijat kérnek cserébe a közvetítő szolgáltatások biztosításáért, hanem utankénti vagy kilométerenkénti jutalékot is. A hagyományos taxitársaságok azonban semmiképp sem tudják mentesíteni gépkocsivezetőiket a piacra lépéshez szükséges állandó költségektől, így árképzéskor az Ublyft mindenképpen elönyt élvez velük szemben.

Az Ublyft többsávos jutalékrendszerében (multi-tiered commisions) a soföröktöl a társaság részére levont jutalék százalékos kulcsa a megtett utak számának függvényében intervallumonként csökken. Minél többet vezet egy gépkocsivezető, annál nagyobb részét tarthatja meg a fuvarozásért járó bevételének. Közvetlenül az Uber és a Lyft piacra lépésekor még csak egysávos jutalékrendszer létezett, de nagyon hamar áttértek a többsávosra (Huet [2015]). Tették ezt úgy, hogy többnyire még a jutalék mértékének emelkedésekor is megérte a sofőrnek az Ublyfttel, nem pedig egy hagyományos taxitársasággal szerződést kötni. 
Huet [2015] idézi az Uber pénzügyi vezetőjének szavait: azért emelik az egyes sávokban a jutalékok mértékét, mert ezt egyelöre könnyedén megtehetik. Így is nagy számban jelentkeznek hozzájuk újabb és újabb soförök. Ez a sávos jutalékrendszer a másodfokú árdiszkriminációs ${ }^{12}$ modell alkalmazása a munkaidő megvásárlására. Minél több munkaerőt vásárol gépkocsivezető partnerétől, annál nagyobb engedményt ad a cég. Ezzel arra ösztönzi a gépkocsivezetőket, hogy egyre többet és többet dolgozzanak, azaz végeredményben több jutalékot fizessenek a szoftverhasználat után. Az Uber által tesztelt rendszer a heti első 15 útra 30 százalékos, a második 15-re 25 százalékos, illetve a további utakra 20 százalékos jutalékot számít fel.

2009-ben, az Uber megalapítása után New Yorkban 20 százalék volt az Uber részére fizetendő jutalék. Huet [2015] pedig arról számol be, hogy volt egy olyan időszak, amikor az Uber a Lyfttel való versengésben egészen 5 százalékosra csökkentette részesedését, a Lyft pedig bizonyos esetekben egyáltalán nem kért jutalékot gépkocsivezetői bevételéből. Ez az engedmény csak rövid ideig tartott, és mind az Uber, mind a Lyft városonként valamelyest eltérően, de mindenütt sávosan növelte a jutalék mértékét. Ma már nemcsak az Uber, hanem a Lyft is elkéri bizonyos esetekben a 30 százalékos részesedést. Campbell [2016] számításai szerint a fix összegü indulási díjat is figyelembe véve az Uber jutaléka átlagosan eléri a bevétel 39 százalékát. Kizárólag hosszabb utak és sürü igénybevétel esetén csökken a jutalék a korábbi 20 százalékot megközelítő értékre.

Mint ahogy korábban már szó volt róla, az Uber, majd a Lyft közvetlen piacra lépése után a fóállású autóvezetők többnyire még valamelyik taxitársaságnál dolgoztak, és leginkább a mellékállású soförök keresték az Ubert vagy a Lyftet. Az ügyesen meghatározott jutalékrendszer azonban mind a fö-, mind a mellékállásban dolgozni kívánók számára, különösen, ha újonnan kívánnak gépkocsivezetőként tevékenykedni, az Ublyftet teszi vonzóbbá. Ezt illusztrálja az 1. ábra ${ }^{13}$ az Ublyft háromsávos jutalékrendszere mellett. $\mathrm{Az}$ a) esetben a hagyományos taxitársaság átalánydíjat és az utak számától függő kis összegü jutalékot kér, valamint a gépkocsivezetőnek a taxipiacra való belépéshez további egyszeri fix kiadással kell számolnia (taxiengedély, licencdíj, a jármüszabványok biztosítása stb.). Ennek egy hétre jutó részét is beszámítjuk a gépkocsivezető heti költségei közé. A b) esetben a hagyományos taxitársaság csak egyösszegü díjat kér a cégéhez csatlakozott gépkocsivezetöktől, továbbá itt is érvényes a piacra lépéshez kapcsolódó fix költség.

Az 1. ábra azt mutatja, hogy a három jutaléksávot alkalmazó Ublyft az egyetlen jutaléksávos taxihoz viszonyítva mindig képes a gépkocsivezetők részére vonzóbb lehetőséget kínálni. Így van ez akkor, amikor a hagyományos taxitársaság nemcsak a társasághoz tartozásért kér jutalékot, hanem a megtett utak számának függvényében is fizetnie kell a gépkocsivezetőknek - a) ábra. És ez érvényes még abban az esetben is - b) ábra -, ha a társaság szolgáltatásaiért csak időegységenként egyszeri díjat számít fel. Mivel a hagyományos taxitársaság gépkocsivezetőjének a piacra

\footnotetext{
${ }^{12}$ Lásd például Paine [1937], Buchanan [1952], Wilson [1993].

${ }^{13}$ Pásztor [2017] 3.1. ábrája hasonló jellegủ gondolatokat tartalmaz a külön-külön működő, egy jutaléksávos Uber és taxi bevételének (a soför kiadásának) illusztrálására.
} 


\section{1. ábra}

Egy hagyományos taxitársaság versus az Ublyft gépkocsivezetőjének autózáson felüli költségei a heti utazások számának függvényében

a) eset

100 dollár

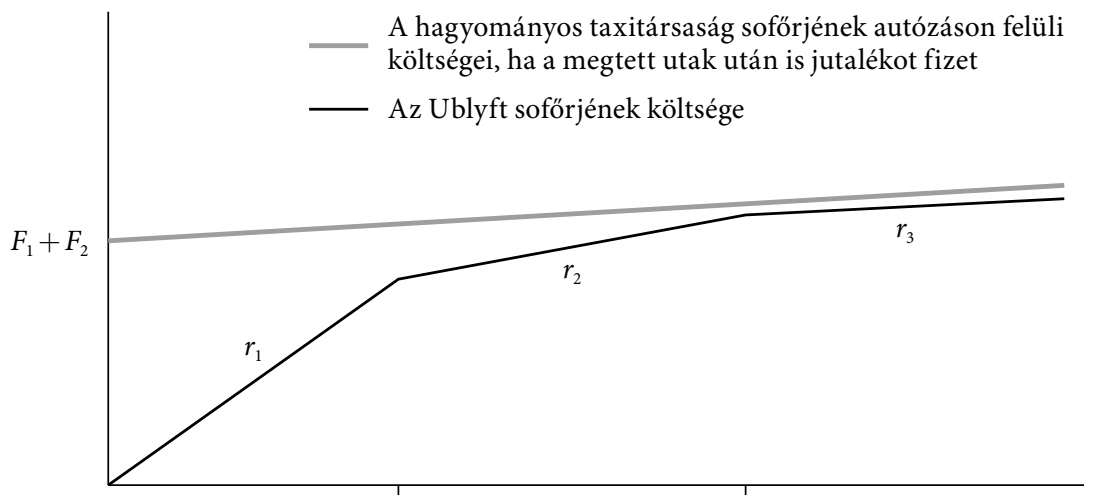

Heti utazások száma

b) eset

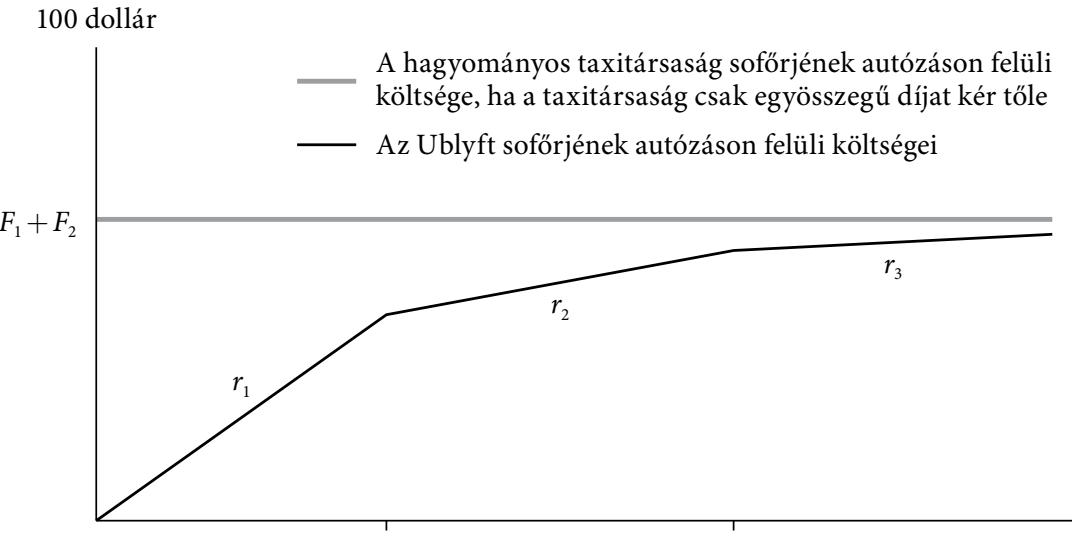

Heti utazások száma

Megjegyzés: az $r_{i}$ az Uberlyft adott sávon belüli jutalékkulcsa $\left(r_{1}>r_{2}>r_{3}\right), F_{1}$ a hagyományos taxitársaság gépkocsivezetőjének piacra lépési költsége, $F_{2}$ pedig átalánydíja.

való belépésért is fizetnie kell, az Ublyftének viszont nem, ezért a hagyományos taxitársaság gépkocsivezetőjének heti időtartamra átszámított fix költsége mindenképpen nagyobb, mint az Ublyfté. Különösen feltűnő a különbség heti kevesebb út megtételekor, pedig ezekben az esetekben az Ublyft jutalékának százalékos kulcsa az összes felvázolt esetet tekintve a legnagyobb.

Legyen $T$ azon utak száma, amennyit egy gépkocsivezető egy hét alatt maximálisan meg tud tenni. $T=t_{1}+t_{2}+t_{3}$. Az első $t_{1}$ útra a legmagasabb jutalékkulcs érvényes $\left(r_{1}\right)$, az utána következő $t_{2}$ útra $r_{2}$, végül az ez után következő $t_{3}$ útra a jutalékkulcs $r_{3}$. A hagyományos taxitársaság gépkocsivezetőjének legyen a heti időtartamra 
átszámított piaci belépési költsége $F_{1}$, és foglalkozzunk kizárólag a $b$ ) esettel, amikor is a társaság heti $F_{2}$ átalánydijat kér gépkocsivezetöjétől. Ismervén az $F_{1}$ és $F_{2}$ összegét, az Ublyft könnyen meg tudja határozni saját paramétereit úgy, hogy

$t_{1} r_{1}+t_{2} r_{2}+t_{3} r_{3}<F_{1}+F_{2}$

legyen. Ugyanakkor, ha az Ublyft képes jól megbecsülni az egyes jutaléksávokba tartozó gépkocsivezetői számát, maximalizálhatja profitját a jutaléksávok és a jutalékkulcsok ügyes meghatározásával. Jelöljük $N_{1}$-gyel az első, $N_{2}$-vel a második és $\mathrm{N}_{3}$-mal a harmadik jutaléksávba tartozó gépkocsivezetők számát! A profitmaximalizálás értelmében

$\left(N_{1}+N_{2}+N_{3}\right) r_{1}+\left(N_{2}+N_{3}\right) r_{2}+N_{3} r_{3} \rightarrow \max$.

Amennyiben a (2) profitmaximalizálás az (1) feltétel mellett valósul meg, akkor minden gépkocsivezetőnek az Ublyfttel érdemes szerződést kötnie. Az (1) feltétel kis módosításával ugyanez érvényes az 1. ábra a) esetére is, amikor is a hagyományos taxitársaság is kér jutalékot a megtett utak számának függvényében.

Még akkor is óriási az Ublyft profitlehetősége, ha nem tartja magát teljesen az (1) feltételhez, és például a sok-sok évig gépkocsivezetőként dolgozók számára mégis vonzóbb a hagyományos taxitársaság. A nagy profitlehetőséget ilyen esetekben is az Ublyft-gépkocsivezetők piaci belépésének elhanyagolható szintű költsége eredményezi, szemben a hagyományos taxitársaságok gépkocsivezetőinek nagy piacra lépési költségével.

A taxitársaságok ma már számos esetben igyekeznek „lemásolni” az Ublyft többféle jutaléksávos rendszerét is. Mivel azonban eltérő szabályozási kötelezettségek érvényesülnek a kétfajta modellben - például a hagyományos taxiscégek gépkocsivezetői semmiképpen sem mentesülnek a taxiengedélyek megszerzésétől -, a hagyományos taxitársaságok mindenképpen hátrányos helyzetből indulnak. Az Európai Bíróság 2017. decemberi határozata ezeket a különbségeket szüntette meg az Európai Unió országaiban, az Egyesült Államokban azonban a legtöbb tagállamban továbbra is különbözik az Ublyft és a taxitársaságok szabályozása.

$\mathrm{Az}$ Ublyft ki is használja a szabályozás adta lehetőségeket, és folyamatosan növeli a járulékkulcsokat. A végeredményt jól tükrözi, hogy 2017 elején leginkább 9 és 12 dollár között mozgott az amerikai Uber- és Lyft-gépkocsivezetők óránkénti jövedelme a jutalék levonása után. Ettől lényegesen csak a New York-i bevételek különböztek az óránkénti 20 dollár feletti értékkel. Mivel a jutalék levonása utáni bevételből még a benzinköltséget és a kocsi amortizációját is fedezni kell, egyes tagállamokban az ottani minimálbért sem éri el a soförök tényleges javadalmazása (Ridester [2017]).

Emellett az egyesült államokbeli Ublyft jelenleg még semmifajta foglalkoztatói szolgáltatást nem nyújt gépkocsivezetői számára, azaz nem létezik fizetett szabadság, betegbiztosítás vagy bármilyen, a későbbi nyugdíjat fedező - akár önkéntes, az Ublyft által szervezett - program. A gépkocsivezetők preferenciái természetesen különböznek a jóléti államokat jellemző szolgáltatások - a nyugdíj, a szabadság és a betegszabadság - értékeit illetően. Lehetnek olyanok, akiknek ezek a jóléti 
szolgáltatások alig-alig képviselnek értéket, mert például van másik - a szóban forgó szolgáltatásokat nyújtó - munkahelyük, s a további jóléti szolgáltatások költségei nagy terhet jelentenének számukra. Nem véletlen, hogy nagyon sok szerző egyértelmüen arra a következtetésre jut, hogy bár az Ublyftet már nem lehet a hagyományos taxitársaságok amúgy is elavult szabályozási keretei közé szorítani, de szükség van egy újfajta - s nem a "mindent megengedő" politikával azonos szabályozási háttérre (például Barglind [2015], Bolton [2015], Cohen-Sundararajan [2015], Geradin [2015], Hall-Krueger [2016], Posen [2015]). Az Ublyft fogyasztóinak és autóvezetőinek érdeke feltétlenül megköveteli, hogy egyértelmü legyen, mit tehet a cég, és mit nem, továbbá mi az, amit feltétlenül meg kell tennie. A jóléti állam vívmányainak átvétele is fontos, de oly módon, hogy ne akadályozza az újonnan kialakuló piaci formákban rejlő fejlődési lendületet.

A kizárólagosan a piaci fejlődést szem előtt tartó, ezért minden körülmények közt az új - elektronikus utasközvetítő platformra épülő - modell érvényesülését támogató „piachívőknek” a közvetett hatásokat is figyelembe kellene venniük: JohnstonLand-Kazlauskas [2018] szerint a platformok segítségével kiközvetített, de adott városhoz, azaz helyhez kötött munkavégzés ugyan csupán nagyon kicsi részét jelenti a munkaerőpiacnak, mégis óriási hatással van a foglalkoztatáshoz kapcsolódó elképzelésekre. Sokan ugyanis úgy vélik, hogy az elektronikus platformra épülő közösségi gazdaság piaci modelljének befolyásoló hatására a formális foglalkoztatás teljességgel el fog tűnni. Ez pedig a munkavégzés minőségének drasztikus romlásához, a megélhetés biztonságának csökkenéséhez és a munkavállalói életminőség rosszabbodásához vezethet. Kétségtelen, hogy az úffajta munkavégzés ellenzőinek tábora rohamosan nő. Az is tény, hogy annak ellenére, hogy az Ublyft gépkocsivezetöpartnerségének óriási szabadsága tűnhet ugyan nagyon vonzónak, de a költségek levonása után megmaradó alacsony javadalmazás már korántsem olyan kívánatos. Ugyancsak nem vonzó a jóléti juttatások hiánya és a vészhelyzetekben a gépkocsivezetők és az utasok bizonytalansága, az érdekérvényesítési lehetőségek hiánya. Az Ublyfthez kapcsolódóan az adózási szabályok betartása is külön vizsgálandó terület.

\section{Összegzés és továbbgondolás}

Az első években ugyan még lassú és ellentmondásos volt az Uber és gyorsan startoló közvetlen vetélytársainak piaci növekedése, mára azonban úgy tűnik, az elektronikus utasközvetítő platformra épülő modell az Egyesült Államok tagállamainak többségében átvette az elsőbbséget a rendeléses személyszállítás piacán. Az alábbiakban összefoglaljuk, hogy a sok ellentmondás ellenére miért is olyan népszerü ma az új modell.

Az utasok számára:

- könnyen és gyorsan hívható, majd a gépkocsivezető érkezése a szoftver segítségével követhetö;

- a kocsik megnövekedett kínálata miatt az egyensúlyi ár általában a korábbi taxiáraknál alacsonyabb, több fogyasztó engedheti meg magának a szolgáltatás igénybevételét; 
- a nagy keresletü időszakokban is biztosan elérhető, és azok, akik hajlandók a szokásos áraknál lényegesen többet fizetni, szinte várakozás nélkül vehetik igénybe a szolgáltatást.

A gépkocsivezetők számára:

- kereseti kiegészítést biztosít azoknak, akik más területen dolgoznak, és még szeretnének többletjövedelemhez jutni;

- azt az érzetet kelti, hogy a gépkocsivezetők teljesen szabadok, úgy és annyit dolgoznak, amennyit szeretnének;

- a fizetendő jutalékok emelése ellenére rövid távon, amikor a gépkocsivezetönek nincs szüksége a szervezett jóléti szolgáltatásokra, javadalmazóbb lehet, mint a hagyományos modell, induláskor nem kell drága beruházásokba fektetni.

A társaságok számára:

- az egyesült államokbeli modell óriási előnye, hogy a cégeknek a saját szerződésükben megfogalmazott szabályokon, a gépkocsivezetői engedélyeken és a minimális alkalmassági teszten kívül egyelőre semmifajta szabályozói kötelezettségnek nem kell eleget tenniük, könnyen megváltoztathatják a gépkocsivezetőknek elöírt szabályokat, beleértve a jutalékrendszert is;

- mivel az új modellben a gépkocsivezetők attól függően tudnak többet keresni, ha minél ötletesebbek és kitartóbbak, erőfeszítéseik a cégek bevételét is egyre jobban növelik;

- a pillanatnyi mélypont ellenére a modell hosszú távon nyereségesnek tünik, mivel a szoftver müködtetése minimális marginális költséggel jár, a gépkocsivezetők pedig rendületlenül termelik a cégek jutalékát;

- a hálózati müködtetésből felhalmozott tapasztalatok és a korábbi nagy bevételekből megvalósítható beruházások lehetővé teszik, hogy rokon és új szolgáltatási területeken is jelentős piaci részesedésre tegyenek szert (például csomagszállítás, vezető nélküli autók bérlése - lásd például Hawkins [2016]).

Az új, elektronikus utasközvetítő platformra épülő modellnek azonban számos, a vele kapcsolatos szereplöket hátrányosan érintő tulajdonsága is van.

Az utasok számára:

- sokkal kevésbé biztonságos, mint a hagyományos taxi: baleset előfordulásakor kizárólag a gépkocsivezetőt vádolhatják, ha nincs a háttérben felelősséget vállaló társaság, a szállítás során előforduló atrocitások esetében is nehéz orvoslást kapni az elszenvedett méltánytalanságokért;

- a hullámzó árak a nagy keresletủ időszakokban olyan magasra szökhetnek, hogy sok potenciális utas nem engedheti meg a rendelést, nem működnek az adott áron történő előrendelési funkciók;

- az internetszolgálat kiesése esetén az utasok nem élhetnek a leintéses taxihívás lehetőségével, és nem tudnak kocsit rendelni.

A gépjármüvezetők és más iparágban dolgozók számára:

- az új modell „klasszikus” változata semmifajta jóléti szolgáltatást (betegség- és nyugdíjbiztosítás, szabadság) nem nyújt a gépkocsivezetők számára; 
- nem teszi lehetővé a gépkocsivezetők közös érdekvédelmét, mindenki csak a saját szerződését ismeri, így a cég önkényes döntése - például a jutalékkulcsok jelentős emelése - ellen csak kilépéssel válaszolhatnak;

- veszélyt jelenthet az összes jövőbeli dolgozóra, az eredeti új piaci modell ugyanis tagadja a formális munkavégzés minden feltételét, és ez könnyen átvihető nagyon sok más iparágba is, ami pedig a munkavégzés jóléti elemeinek leépülését jelentheti.

A társaságok számára:

- a szoftver használata ugyan óriási profitlehetőségeket nyújt, de az új modellel szembeni ellenállás számos költséges és a profitabilitást veszélyeztető jogi pert indukál;

- hosszú távon az új modell nem feltétlenül fenntartható: elképzelhető, hogy a szabályozás megváltozik, és az elektronikus utasközvetítő platformra Európához hasonlóan másutt is bevezetik a hagyományos személyszállításra vonatkozó előírásokat.

Összességében úgy tűnik, hogy a hívásos személyszállítás piacán a többirányú technikai fejlődés eredményeként hasonló jellegü gyors változás zajlik le, mint aminek a vezetékes és mobiltelefonos iparágban lehettünk szemtanúi az 1980-as években. Míg azonban a távközlés piaci változásai nem rengették meg a munkaerőpiacot, a megosztáson alapuló (sharing economy) új iparágakra ez korántsem mondható el. A tanulmányban említett két földrajzi térség, az Egyesült Államok és Európa esetében az előbbi szabályozási háttere sokkal megengedőbb, de itt is változás várható. Európában pedig 2017 végétől az elektronikus utasközvetítő platformon müködő szolgáltatók kénytelenek a hagyományos hívásos utasszállító cégekkel azonos szabályozásnak megfelelni. Nem biztos azonban, hogy ez az egyetlen megoldás az Ublyft feltörekvő piacának szabályozására, és a továbbiakban sem érdemes teljesen elvetni egy új típusú szabályozási rendszer lehetőségét. Ennek az elemei azonban ma még egyáltalán nem körvonalazódnak.

\section{Hivatkozások}

BARGLIND, K. [2015]: Innovation, Technology, and Transportation: The Need to Address On-Demand Ridesharing and Modernize Outdated Taxi Regulations in the US. Wisconsin International Law Journal, Vol. 33. No. 4. 701-727. o.

Bolton, A. [2015]: Regulating Ride-Share Apps: A Study on Tailored Reregulation Regarding Transportation Network Companies, Benefitting Both Consumers and Drivers. Cumberland Law Review, Vol. 46. No. 1. 102-143. o. https://cumberlandlawreview.files.wordpress. com/2015/11/bolton-ride-share.pdf.

Buchanan, J. M. [1952]: The theory of monopolistic quantity discounts. The Review of Economic Studies, Vol. 20. No. 3. 199-208. o. https://doi.org/10.2307/2295890.

Calfas, J. [2017]: Uber's $\$ 708$ Million Loss Was Actually Good by Uber Standards. Fortune, június 1. http://fortune.com/2017/06/01/uber-first-quarter-2017.

Campbell, H. [2016]: What's The Real Commision That Uber Takes From Drivers? Maximum Ridesharing Profits, http://maximumridesharingprofits.com/whats-real-commisionuber-takes-drivers/. 
Christensen, C. M.-Bower, J. L. [1996]: Customer power, strategic investment, and the failure of leading firms. Strategic Management Journal, Vol. 17. No. 3. 197-218. o. https://doi. org/10.1002/(sici)1097-0266(199603)17:3<197::aid-smj804>3.0.co;2-u.

Cohen, M.-Sundararajan, A. [2015]: Self-regulation and innovation in the peer-to-peer sharing economy. University of Chicago Law Review, Vol. 82. No. 1. 116-133. o.

Cohen, P.-Hahn, R.-Hall, J.-Levitt, S.-Metcalfe, R. [2016]: Using Big Data to Estimate Consumer Surplus: The Case of Uber. NBER Working Paper, No. 22627. https://doi. org/10.3386/w22627.

Cramer, J.-Krueger, A. B. [2016]: Disruptive change in the taxi business: The case of Uber. The American Economic Review, Vol. 106. No. 5. 177-182. o. http://dx.doi.org/10.1257/ aer.p20161002.

DeMasi, A. A. [2016]: Uber: Europe's Backseat Driver for the Sharing Economy. Creighton International and Comparative Law Journal, Vol. 7. 73-85. o.

ECJ [2017]: Asociación Profesional Elite Taxi kontra Uber Systems Spain, SL. A Bíróság ítélete (nagytanács), 2017. december 20. Court Of Justice of the European Union, Luxembourg, Press Release, No. 136/17. https:/g8fip1kplyr33r3krz5b97d1-wpengine.netdna-ssl.com/ wp-content/uploads/2017/12/uber-ecj-press-release.pdf.

Geradin, D. [2015]: Uber and the Rule of Law: Should Spontaneous Liberalization Be Applauded or Criticized? Competition Policy International. George Mason Law and Economics Research Paper, No. 1553. https://www.law.gmu.edu/assets/files/publications/ working_papers/1553.pdf.

Hahn, R.-Metcalfe, R. [2017]: The Ridesharing Revolution: Economic Survey and Synthesis. Megjelent: Kominers, S. D.-Teytelboym, A. (szerk.): More Equal by Design: Economic design responses to inequality. Oxford University Press, Vol. IV. https://www.brookings. edu/wp-content/uploads/2017/01/ridesharing-oup-1117-v6-brookings1.pdf.

Hall, J. V.-Krueger, B. [2016]: An Analysis of the Labor Market for Uber's Driver-Partners in the United States. NBER Working Paper, No. 22843. http://dx.doi.org/10.3386/w22843.

Harris, S. D.-Krueger, A. B. [2015]: A Proposal for Modernizing Labor Laws for TwentyFirst-Century Work: The Independent Worker. Discussion Paper, No. 2015-1. Hamilton Project, Brookings, http://www.hamiltonproject.org/assets/files/modernizing_labor_ laws_for_twenty_first_century_work_krueger_harris.pdf.

Hawkins, A. J. [2016]: You Can Hail a Self-Driving Uber in San Francisco Starting Today: Is Silicon Valley ready for autonomous ride-sharing? The Verge, december 14. https:// www.theverge.com/2016/12/14/13921514/uber-self-driving-car-san-francisco-launchvolvo-xc90.

Huet, E. [2015]: Uber Tests Taking Even More From Its Drivers With 30\% Commission. Forbes, május 18. http://www.forbes.com/sites/ellenhuet/2015/05/18/uber-new-uberxtiered-commission-30-percent.

Johnston, H.-Land-Kazlauskas, C. [2018]: Organizing On-Demand: Representation, Voice, and Collective Bargaining in the Gig Economy. Conditions of Work and Employment Series, No. 94. ILO, Genf.

Kollewe, J. [2017a]: Uber president quits firm saying its values are 'inconsistent' with his. The Guardian, március 20. https://www.theguardian.com/technology/2017/mar/20/uberpresident-quit-as-firm-was-inconsistent-with-his-values.

Kollewe, J. [2017b]: New Uber Blow as European Legal Adviser Says Service Should Be Licensed like Taxis. The Guardian, május 11. https://www.theguardian.com/technology/ 2017/may/11/uber-cabs-taxis-us-app-ecj. 
Livemint [2018]: Why Uber 2018 is unlike Amazon 2002. Livemint, február 22. www. livemint.com/Companies/Ju3jiAlNQu1Sjn8A0TrNFI/Why-Uber-2018-is-unlikeAmazon-2002.html.

Paine, C. L. [1937]: Some aspects of discrimination by public utilities. Economica, Vol. 4. No. 16. 425-439. o. http://dx.doi.org/10.2307/2626878.

PÁsztor Szabolcs [2017]: Hagyományos taxi kontra Uber. Új szabályozói kihívások a taxipiacon. TDK-dolgozat. Budapesti Corvinus Egyetem, Budapest, http://szd.lib.unicorvinus.hu/10476.

Posaner, J.-Sauer, N. [2017]: Where you can catch an Uber. Politicopro, december 20. https://www.politico.eu/pro/where-you-can-catch-an-uber.

Posen, H. A. [2015]: Ridesharing in the Sharing Economy: Should Regulators Impose Uber Regulations on Uber. Iowa Law Review, Vol. 101. 405-433. o.

Ram, A.-Murgia, M.-Powley, T. [2017]: Uber comes to end of ride at London's City Hall. Financial Times, szeptember 22. https://www.ft.com/content/2b12a62a-9f8c-11e7-8cd4$932067 \mathrm{fbf} 946$.

Rideshareapps [2017]: The Year The Rideshare Industry Crushed The Taxi [Infographic]. Rideshareapps.com, https://rideshareapps.com/2015-rideshare-infographic.

Ridester [2017]: How Much Do Uber Drivers Make in 2017? [The Inside Scoop]. Ridester. com, https://www.ridester.com/how-much-do-uber-drivers-make.

Schneider, T. [2016]: Taxi, Uber, and Lyft Usage in New York City. toddwschneider.com, április 16. (folyamagosan frissítve) http://toddwschneider.com/posts/taxi-uber-lyft-usagenew-york-city.

Schuetz, J. [2016]: Where Should Online Peer-to-Peer Markets Thrive? FEDS Notes, december 22. Board of Governors of the Federal Reserve System (U.S.), http://dx.doi. org/10.17016/2380-7172.1894.

STIGLER, G. J. [1971]: The theory of economic regulation. The Bell Journal of Economics and Management Science, Vol. 2. No. 1. 3-21. o. http://dx.doi.org/10.2307/3003160.

Szabó Katalın [2017]: Intézményi vállalkozások: intézményi újítások - létező intézmények kombinációjával. Vezetéstudomány, 48. évf. 3. sz. 2-14. o.

Wilson, R. B. [1993]: Nonlinear Pricing. Oxford University Press, Oxford.

Wyman, K. M. [2017]: Taxi Regulation in the Age of Uber, N.Y.U. Journal of Legislation and Public Policy, Vol. 20. No. 1. 2-100. o. 